\title{
PENERAPAN MODEL POE2WE PADA PEMBELAJARAN FISIKA SMA MATERI FLUIDA DINAMIS BERBANTUAN PhET SIMULATIONS
}

\author{
Riza Hasanudin ${ }^{1}$, Nana $^{2}$ \\ Pendidikan Fisika Fakultas Keguruan dan Ilmu Pendidikan Universitas Siliwangi \\ Tasikmalaya, Jawa barat, Indonesia \\ Email: rizahasanudin2000@gmail.com \\ nana@unsil.ac.id
}

\begin{abstract}
Abstrak
Penelitian ini merupakan bentuk penerapan model pembelajaran POE2WE dalam pembelajaran fisika berbantuan media virtual laboratorium yaitu Phet Simulations. Tujuan penelitian ini adalah: (1) mengetahui dan menganalisis penerapan model POE2WE dalam pembelajaran fisika SMA materi fluida dinamis dengan bantuan media virtual laboratorium PhET Simulations, (2) mengetahui kelebihan penggunaan simulasi virtual PhET dalam pembelajaran fisika pada materi fluida dinamis dengan menggunakan model POE2WE. Materi yang dipilih adalah materi fisika SMA kelas XI mengenai Fluida Dinamis. Penelitian ini menggunakan pendekatan kualitatif berupa pengumpulan data teoritis dengan metode deskriptif dan teknik kajian pustaka. Hasil penelitian ini menujukan bahwa: (1) dalam pembelajaran fisika dengan menggunakan model POE2WE yaitu pada sintaks Observation sangat cocok dibantu dengan media virtual laboratorium PhET Simulations, (2) penggunaan PhET Simulations dalam pembelajaran fisika dengan model POE2WE memiliki beberapa kelebihan diantaranya : mudah dalam pengoperasiannya, dapat meningkatkan pemahaman konsep siswa, dapat meningkatkan motivasi belajar siswa, mengurangi rasa kekhawatiran siswa akan kecelakaan dalam melakukan eksperimen, dapat meningkatkan hasil belajar siswa, serta bisa dijadikan alternatif apabila fasilitas praktikum minim agar tujuan pembelajaran yang diharapkan tetap dapat tercapai.
\end{abstract}

Kata kunci: Fisika, POE2WE, PhET Simulations

\section{PENDAHULUAN}

Seiring dengan kemajuan zaman proses pembelajaran dalam dunia pendidikan juga ikut mengalami perubahan. Dimana proses pembelajaran yang asalnya guru berperan sebagai pusat pembelajaran (teaching center learning) yang hanya berperan mentransfer ilmu pengetahuan kepada peserta didik kini berubah peserta didiklah yang menjadi pusat pembelajaran (student center learning). Dimana peserta didik berperan aktif dalam mengontruksi pemahamannya secara mandiri, dan guru berperan sebagai fasilitator. Salah satu model pembelajaran yang berpusat pada peserta didik adalah model pembelajaran POE2WE. Menurut Nana, dkk (2014) Model pembelajaran POE2WE merupakan pengembangan dari model pembelajaran POE, model pembelajaran TTW, dan model pembelajaran konstruktivis. Sintaks model POE2WE adalah memprediksi (Prediction), mengobservasi (Observation), menjelaskan (Explanation), elaborasi (Elaboration), menulis (Write), dan mengevaluasi (Evaluation).

Salah satu permasalahan dalam kegiatan pembelajaran diberbagai sekolah diindonesia adalah kurangnnya fasilitas penunjang proses pembelajaran. Salah satu fasilitas pembelajaran yang sering mengalami kekurangan adalah fasilitas praktikum. Hal ini berkaitan dengan proses pembelajaran fisika 
menggunakan model POE2WE dimana pada sintaks Observation biasanya membutuhkan alat praktikum dalam keperluan mengobservasi. Pembelajaran fisika erat kaitannya dengan kegaitan mengobservasi ataupun peraktikum agar peserta didik dapat mengontruksi pemahamannya secara mandiri. Hal ini sejalan dengan pendapat Rustaman (dalam Suryaningsih, 2017) Praktikum merupakan kegiatan pembelajaran yang bertujuan agar siswa mendapat kesempatan untuk menguji untuk menguji dan mengaplikasikan teori dengan menggunakan fasilitas laboratorium maupun diluar laboratorium. Praktikum dalam pembelajaran merupakan metode yang efektif untuk mencapai tujuan pembelajaran.

Berbagai media pembelajaran telah berkembang seiring dengan berkembangnya zaman terutama media non cetak. Media non cetak berupa aplikasi atau software dapat menjadi alternatif untuk mengatasi kurangnya sarana penunjang pembelajaran khususnya kegiatan praktikum agar pembelajaran dapat tetap berlangsung guna mencapai tujuan pembelajaran. Menurut Nana, dkk (2019), pada era digital atau era informasi sekarang ini ilmu pengetahuan dan teknologi berkembang dengan pesat. Perkembangan ini memiliki dampak semakin terbuka dan tersebarnya informasi dan pengetahuan dari dan ke seluruh dunia menembus batas jarak, tempat, ruang dan waktu. Kenyataannya dalam kehidupan manusia di era digital ini akan selalu berhubungan dengan teknologi. Teknologi pada hakikatnya adalah proses untuk mendapatkan nilai tambah dari produk yang dihasilkannya agar bermanfaat. Teknologi telah mempengaruhi dan mengubah manusia dalam kehidupannya sehari-hari, sehingga jika sekarang ini 'gagap teknologi' maka akan terlambat dalam menguasai informasi, dan akan tertinggal pula untuk memperoleh berbagai kesempatan maju. Informasi memiliki peran penting dan nyata, pada era masyarakat informasi (information society) atau masyarakat ilmu pengetahuan (knowledge society). Sedangkan menurut Sarager (2016), seiring dengan pesatnya perkembangan ilmu pengetahuan dan teknologi, media elektronik dapat menjadi solusi dari kendala yang ditemui oleh pendidik dan peserta didik saat melakukan pembelajaran dengan konten materi yang berkarakteristik abstrak. Percobaan yang sulit dilakukan di laboratorium real, yang umumnya disebabkan minimnya alat-alat praktikum yang memadai, dapat dilakukan menggunakan media laoratorium virtual yang dijalankan dengan komputer.

Salah satu media non cetak yang dapat digunakan dalam keperluan praktikum sains khususnya fisika adalalah PhET Simulations. Menurut Mubarok (2014), PhET merupakan ciptaan dari komunitas sains melalui PhET Project di University of Colorado, USA. PhET (Physics Education Technology) merupakan sebuah situs yang menyediakan simulasi pembelajaran fisika yang dapat di download secara gratis untuk kepentingan pengajaran dikelas atau dapat digunakan secara individu. Simulasi interaktif PhET Colorado merupakan media simulasi interaktif yang menyenangkan dan berbasis penemuan yang berupa software dan dapat digunakan untuk memperjelas konsep-konsep fisis atau fenomena yang telah dipraktikumkan. Dengan menggunakan media PhET Simulation diharapkan siswa mampu dan dapat menerapkan konsep yang telah diperoleh selama pembelajaran secara teori dan praktikum ke simulasi yang terdapat dalam media PhET tersebut.

Berdasarkan uraian diatas, maka disusunlah penelitian yang berjudul "Penerapan Model POE2WE Pada Pembelajaran Fisika SMA Materi Fluida Dinamis Berbantuan PhET Simulations".

\section{METODE PENELITIAN}

Penelitian ini menggunakan pendekatan kualitatif berupa pengumpulan data teoritis dengan metode deskriftif. Dengan metode ini penulis dapat menguraikan permasalahan yang dibahas secara jelas dan komprehensif. Pengumpulan data teoritis menggunakan teknik kajian pustaka, teknik kajian pustaka berarti bahwa peneliti mengambil data melalui kegiatan membaca literatur yang relevan dengan kajian penelitian yang dilakukan. Data dikumpulkan untuk 
dianalisis kemudian disajikan dalam hasil dan pembahasan agar dapat dibuat kesimpulan.

\section{HASIL DAN PEMBAHASAN}

Penerapan model POE2WE dalam pembelajaran fisika dikhususkan pada materi fluida dinamis. Dalam proses pembelajaran pada sintaks Observation dibantu dengan menggunakan media PhET Simulations sebagai bentuk inovasi dalam kegiatan pembelajaran khususnya pada materi pembelajaran yang memerlukan fasilitas praktikum dan sebagai bentuk pemanfaatan teknologi dalam proses pembelajaran.

Pembelajaran menggunakan media non cetak memang sangat perlu dikembangkan agar proses pembelajaran dapat dilakukan secara efektif, efisien dan menyenangkan. Tentu saja perlu peran ekstra dari seorang guru agar bisa mengemas suatu pembelajaran menjadi lebih menyenangkan dan tidak membosankan bagi peserta didik, terutama dalam pembelajaran fisika yang seakan-akan menjadi salah satu mata pelajaran yang ditakuti siswa. Dengan memilih model pembelajaran yang tepat dan memilih media yang tepat bisa menjadi jawaban dari tantangan seorang guru dalam menciptakan suasana belajar dikelas yang menyenangkan. Menurut Nana, dkk (2020) Model pembelajaran POE2WE dapat menjadikan siswa sebagai subjek di dalam pembelajaran. Siswa aktif dalam menemukan suatu konsep melalui pengamatan atau eksperimen secara langsung, bukan dari menghafal buku materi maupun penjelasan dari guru. Model ini memungkinkan siswa aktif dalam proses pembelajaran, memberikan kesempatan kepada siswa untuk mengkonstrukssi pengetahuannya, mengkomunikasikan pemikirannya dan menuliskan hasil diskusinya sehingga siswa lebih menguasai dan memahami konsep yang akan berdampak pada peningkatan prestasi belajar siswa.

Sementara itu media yang dipilih adalah virtual laboratorium PhET Simulations yang diterapkan dalam salah satu sintaks model pembelajaran POE2WE yaitu Observations. Menurut Nana, dkk (2019) Tahap Observation yaitu untuk membuktikan prediksi yang telah di buat oleh peserta didik. Peserta didik diajak melakukan eksperimen berkaitan dengan masalah atau persoalan yang di temukan. Selanjutnya peserta didik mengamati apa yang terjadi, kemudian peserta didik menguji kebenaran dari dugaan sementara yang telah dibuat. Tahap Observation pada model POE2WE identik dengan fase Exploration pada pendekatan konstruktivistik.

Langkah-langkah pembelajaran fisika materi fluida dinamis menggunakan model POE2WE berbantuan media PhET Simulatios sebagai berikut:

\section{Prediction}

Tahap prediction merupakan tahap pertama dalam pembelajaran menggunakan model POE2WE, pada tahap ini siswa memprediksi permasalahan yang berkaitan dengan materi fluida dinamis baik yang ditanyakan oleh guru ataupun yang ditampilkan guru pada slide power point, misalnya guru menanyakan hubungan antara luas penampang, tekanan, dan kecepatan pada fluida dinamis. Tahap ini bertujuan untuk mengetahui pemahaman awal siswa terkait materi fluida dinamis.

2. Observation

Pada tahap ini siswa dapat membuktikan secara langsung prediksi mereka melalui kegiatan observasi, pada tahap ini kegiatan observasi menggunakan media virtual laboratorium PhET Simulatios untuk menguji hipotesis yang telah meraka buat. Phet Simulations dipilih untuk menjadi alternatif apabila kekurangan sarana penunjang dalam kegiatan observasi, supaya proses pembelajaran tetap dapat berlangsung dan tujuan pembelajaran dapat tercapai. Selain itu Phet Simulations juga memiliki beberapa kelebihan sebagaimana yang 
dikemukakan Sari, dkk, (2013) Kelebihan dari Simulasi PhET yakni dapat dijadikan suatu pendekatan pembelajaran yang membutuhkan keterlibatan dan interaksi dengan siswa, mendidik siswa agar memiliki pola berfikir kontruktivisme, dimana siswa dapat menggabungkan pengetahuan awal mereka dengan temuan- temuan virtual dari simulasi yang dijalankan, membuat pembelajaran lebih menarik karena siswa dapat belajar sekaligus bermain pada simulasi tersebut, dan memvisualisasikan konsep-konsep IPA dalam bentuk model. Sedangkan menurut Dewi, dkk (2017) Pembelajaran fisika menggunakan Simulasi PhET efektif meningkatkan hasil belajar, interaksi siswa selama pembelajaran, dan motivasi belajar siswa.

3. Eksplanation

Pada tahap ini siswa menjelaskan hasil observasi dalam bentuk presentasi didepan kelas. Apakah prediksi yang telah mereka buat terbukti benar pada kegiatan observasi, atau malah sebaliknya. Apabila ada kekeliruan dalam hasil observasi siswa, guru berperan untuk meluruskan atau memberi tahu jawaban yang benar terkait kegiatan observasi.

4. Elaboration

Pada tahap ini siswa dapat menghubungkan teori dari materi fluida dinamis dengan kehidupan sehari-hari. Peran guru disini yaitu mendorong siswa untuk menentukan penerapan konsep fluida dinamis dalam kehidupan sehari-hari.

5. Write

Pada tahap ini siswa menuliskan kesimpulan dari serangkaian kegiatan pembelajaran yang telah dilakukan berkenaan dengan materi fluida dinamis. Pada tahap ini siswa dapat merefleksikan pemahaman yang telah mereka dapat kedalam bentuk tulisan.

6. Evaluation

Tahap ini merupakan tahap untuk mengukur sejauh mana siswa memahami materi yang telah dipelajari dalam tahap sebelumnya. Guru dapat memberikan pertanyaan secara lisan atau pun tulisan.

Selama proses pembelajaran
berlangsung, sebagian besar r siswa
menunjukan minat yang tinggi dalam
melakukan eksperimen. Siswa tidak merasa
kesulitan dalam megoperasikan PhET
Simulation sehingga mereka bebas melakukan
eksplorasi. Merekapun tidak khawatir akan
menimbulkan kesalahan atau kecelakaan saat
melakukan eksperimen
(Khoiriyah, et al., 2015).

PheT dapat menjadi alatbantu ketika guru melakukan proses pembelajaran, selain itu PhET mampu menyampaikan informasi secara efektif dan efisien terutama pada mata pelajaran yang kaya akan konsep dan sulit dipahami. Media PhET tidak hanya dapat digunakan pada materi teori kinetik gas, tetapi juga dapat digunakan pada materi fisika lainnya seperti gelombang, energi dan perubahan energi, efek fotolistrik, dan lainlain (Oktavia, 2016).

Penggunaan media virtual seperti PhET lebih mampu meningkatkan pemahaman siswa. Selama kegiatan eksperimen berlangsung, siswa dapat mengamati kesesuaian antara hipotesis dengan fakta yang terkait eksperimen yang sedang dilaksanakan. Apabila hipotesis yang dibuat siswa terkait masalah sudah sesuai dengan fakta yang terjadi selama proses eksperimen, maka hal ini dapat memperkuat pemahaman siswa mengenai materi yang sedang dipelajari (Jauhari, et al., 2016).

\section{KESIMPULAN}

Berdasarkan penelitian di atas dapat disimpulkan bahwa: 1). Dalam pembelajaran fisika dengan menggunakan model POE2WE 
yaitu pada sintaks Observation sangat cocok dibantu dengan media virtual laboratorium PhET Simulations, 2). Penerapan PhET Simulations dengan menggunakan model POE2WE memiliki beberapa keuntungan diantaranya : mudah dalam pengoperasiannya, dapat meningkatkan pemahaman konsep siswa, dapat meningkatkan motivasi belajar siswa, mengurangi rasa kekhawatiran siswa akan kecelakaan dalam melakukan eksperimen, dapat meningkatkan hasil belajar siswa, serta bisa dijadikan alternatif apabila fasilitas praktikum minim agar tujuan pembelajaran yang diharapkan tetap dapat tercapai.

\section{UCAPAN TERIMAKASIH}

Alhamdulillah puji syukur kehadirat Allah swt, karena atas karuniannya peneliti dapat menyelesaikan jurnal ini. Peneliti sadari bahwa jurnal ini tidak akan selesai tanpa doa, dan dukungan dari berbagai pihak. Adapun dalam kesempatan ini peneliti ingin mengucapkan banyak terima kasih kepada:

1. Dr. Nana, M.Pd. yang telah ikut serta membimbing dan memberikan arahan agar peneliti menyelesaikan jurnal ini.

2. Semua pihak yang terlibat dalam proses pembuatan jurnal ini yang tidak dapat disebutkan satu persatu.

\section{REFERENSI}

Dewi, T. S., Maghfiroh, H. N. I. S., \& Fitri, N. (2017). Pembelajaran Menggunakan Animasi Komputer PHET (Physics Education Technology) Simulation pada Materi Efek Fotolistrik. Prosiding SNPBS (Seminar Nasional Pendidikan Biologi dan Saintek) Ke-2.

Jauhari, T., Hikmawati, H., \& Wahyudi, W. (2017). Pengaruh model pembelajaran berbasis masalah berbantuan media phet terhadap hasil belajar fisika siswa kelas X SMAN 1

Gunungsari tahun pelajaran 2015/2016. Jurnal Pendidikan Fisika dan Teknologi, 2(1), 7-12.

Khoiriyah, I., Rosidin, U., \& Suana, W. (2015). Perbandingan hasil belajar menggunakan phet simulation dan kit optika melalui inkuiri terbimbing. Jurnal Pembelajaran Fisika, 3(5).

FATHUL MUBARROK, M. U. H. A. M. M.

A. D. (2014). Penerapan pembelajaran fisika pada materi cahaya dengan media PhET simulations untuk meningkatkan pemahaman konsep siswa di SMP. Inovasi Pendidikan Fisika, 3(1).

Nana, S., Akhyar, M., \& Rochsantiningsih, D. (2014). The Development Of Predict, Observe, Explain, Elaborate, Write, And Evaluate (POE2WE) Learning Model In Physics Learning At Senior Secondary School. Development, 5(19).

Nana, N., \& Surahman, E. Pengembangan Inovasi Pembelajaran Digital Menggunakan Model Blended POE2WE di Era Revolusi Industri 4.0. In Prosiding SNFA (Seminar Nasional Fisika dan Aplikasinya) (Vol. 4, pp. 82-90).

Nana, Surahman, E. POE2WE (Prediction, Observation, Explanation, Elaboration, Write and Evaluation) Model as Alterative for Learning Physics in Industrial Revolution 4.0 Era. Advances in Social Science, Education and Humanities Research. 397(2).

Oktavia, F. (2016). Perbandingan Hasil 
Belajar dengan Menggunakanphysics Education Technology (Phet)

Interactive Simulation dan Microsoft Powerpointdi Sman 4 Banda

Aceh. Jurnal Ilmiah Mahasiswa Pendidikan Fisika, 1(3).

Saregar, A. (2016). Pembelajaran pengantar fisika kuantum dengan memanfaatkan media phet simulation dan LKM melalui pendekatan saintifik: Dampak pada Minat dan Penguasaan Konsep Mahasiswa. Jurnal Ilmiah Pendidikan Fisika Al-Biruni, 5(1), 53-60.

SARI, P., \& Permata, D. Y. A. H. (2013). Uji Coba Pembelajaran IPA dengan LKS sebagai Penunjang Media Virtual PhET untuk Melatih Keterampilan Proses pada Materi Hukum Archimedes. PENDIDIKAN SAINS, 1(02).

Suryaningsih, Y. (2017). Pembelajaran berbasis praktikum sebagai sarana siswa untuk berlatih menerapkan keterampilan proses sains dalam materi biologi. BIO EDUCATIO:(The Journal of Science and Biology Education), 2(2). 